\title{
Opracowanie receptur zaczynów cementowych do uszczelniania otworów o podwyższonych temperaturach w rejonie Karpat
}

\section{Development of cement slurries for sealing boreholes with elevated temperatures in the Carpathian region}

\author{
Łukasz Kut \\ Instytut Nafty i Gazu - Państwowy Instytut Badawczy
}

\begin{abstract}
STRESZCZENIE: Prace związane z wykonywaniem otworu wiertniczego o dużej głębokości (przekraczającej 3000 m) muszą uwzględnić specyficzne warunki panujące na jego spodzie, tj. temperaturę przekraczającą $90^{\circ} \mathrm{C}$ oraz ciśnienie powyżej $60 \mathrm{MPa}$. Tak trudne warunki otworowe nieraz przysparzały wiele problemów w czasie opracowywania odpowiednich składów zaczynów cementowych stosowanych podczas uszczelniania kolumn rur okładzinowych. Z roku na rok firmy wiertnicze wykonują coraz głębsze i bardziej skomplikowane otwory, przekraczające $3000 \mathrm{~m}$, które podczas uszczelniania kolumny rur okładzinowych wymagają zastosowania specjalnie opracowanych receptur zaczynów uszczelniających. W przypadku znacznej głębokości otworu (na której panuje bardzo wysoka temperatura i ciśnienie) poważnym problemem jest zapewnienie długiego czasu przetłaczania zaczynu cementowego, który powinien charakteryzować się niską lepkością, niewielkim lub zerowym odstojem wody oraz jak najniższą filtracją. Należy zatem dobierać odpowiednie środki opóźniające, które są odporne na działanie wysokich temperatur, oraz dodatki zapewniające właściwe parametry technologiczne zaczynu i kamienia cementowego. Wraz ze wzrostem głębokości otworu wiertniczego wzrastają również parametry ciśnienia i temperatury. Wody złożowe (solanki o różnej mineralizacji) w dużym stopniu oddziałują na stwardniały zaczyn cementowy, dlatego zaczyny cementowe przeznaczone do dużych głębokości powinny zawierać w swoim składzie dodatki: podnoszące odporność termiczną, opóźniające wiązanie, obniżające filtrację oraz poprawiające odporność na korozję chemiczną wywołaną działaniem solanek złożowych. Celem badań laboratoryjnych było opracowanie innowacyjnych receptur zaczynów cementowych do uszczelniania otworów o podwyższonych temperaturach (do około $130^{\circ} \mathrm{C}$ ), zarówno naftowych, jak i geotermalnych, w rejonie Karpat. Podczas realizacji tego tematu wykonywano badania laboratoryjne zaczynów cementowych oraz otrzymanych z nich kamieni cementowych. W związku z zainteresowaniem przemysłu pozyskiwaniem energii z innych źródeł niż ropa naftowa i gaz ziemny szerszym zakresem badań laboratoryjnych objęte zostały zaczyny cementowe do uszczelniania otworów geotermalnych o regulowanych parametrach reologicznych, które mogą być użyte w wysokich temperaturach złożowych do uszczelniania głębokich otworów wiertniczych. Zaczyny cementowe zarabiano wodą wodociągową z dodatkiem chlorku potasu w ilości 3\%, 6\% i 10\% bwow (w stosunku do ilości wody). Do wody zarobowej dodawano kolejno środek odpieniający, regulujący czas wiązania i gęstnienia, upłynniający i obniżający filtrację. Zaczyny cementowe sporządzono z dodatkiem lateksu w ilości 10\% i stabilizatora lateksu w ilości 1\% bwoc (oba składniki w stosunku do masy suchego cementu). Pozostałe składniki: mikrocement (nanocement), mikrosilikę, hematyt i cement mieszano ze sobą i wprowadzano następnie do wody zarobowej. Wszystkie zaczyny cementowe sporządzano na bazie cementu wiertniczego G. Po połączeniu wszystkich składników zaczyn cementowy mieszano przez 30 minut, a następnie wykonywano pomiary laboratoryjne takie jak: gęstość, rozlewność, odczyty z aparatu Fann, odstój wody, filtrację, czas gęstnienia. Z opracowanych zaczynów cementowych wybrano te o najlepszych parametrach reologicznych, następnie sporządzono $\mathrm{z}$ nich próbki kamieni cementowych. Zaczyny cementowe wiązały przez $48 \mathrm{~h}$ w środowisku wysokiej temperatury i ciśnienia (warunki otworopodobne). Otrzymane kamienie cementowe poddano badaniu: wytrzymałości na ściskanie, wytrzymałości na zginanie, przyczepności do rur stalowych oraz porowatości.
\end{abstract}

Słowa kluczowe: zaczyn cementowy, otwór geotermalny, kamień cementowy, parametry reologiczne, parametry mechaniczne, parametry technologiczne.

ABSTRACT: Works related to the drilling of a deep borehole must take into account the specific conditions at its bottom. This applies especially to high temperatures, exceeding $90-100^{\circ} \mathrm{C}$, and pressures of $60-80 \mathrm{MPa}$. Such difficult downhole conditions have often posed many problems when developing appropriate compositions of cement slurries used for sealing columns of casing pipes. With each passing year, drilling companies make deeper and more complicated boreholes, more and more often exceeding $3000 \mathrm{~m}$, which require the use of specially developed recipes of cement slurries when sealing the casing column. In deep boreholes (with very high temperature and pressure),

Autor do korespondencji: Ł. Kut, e-mail: lukasz.kut@inig.p1

Artykuł nadesłano do Redakcji: 20.11.2020 r. Zatwierdzono do druku: 03.03.2021 r. 
a serious problem is to ensure a long pumping time of the cement slurry, which should be characterized by low viscosity, little or no free water and the lowest filtration possible. Therefore, it is necessary to select appropriate retardants that are resistant to high temperatures and additives ensuring the appropriate technological parameters of the slurries and cement stone. Pressure and temperature parameters increase with the depth of the borehole. Reservoir waters (brines of different mineralization) largely affect the hardened cement slurry, therefore cement slurries intended for deep boreholes should contain in their composition additives that increase thermal resistance, delay setting, lower filtration and improve resistance to chemical corrosion caused by the action of brines reservoir. The aim of the laboratory research was to develop innovative formulas of cement slurries for sealing boreholes, both crude oil and geothermal, with increased temperatures (up to about $130^{\circ} \mathrm{C}$ ) located in the Carpathian region. During the implementation of the topic, laboratory tests were carried out on both cement slurries and cement stones obtained from them. Due to the industry's interest in acquiring energy from sources other than crude oil and natural gas, a broader scope of laboratory tests covered cement slurries for sealing geothermal boreholes with controlled rheological parameters, which can be used at high reservoir temperatures to seal deep boreholes. The cement slurries were prepared with tap water with the addition of potassium chloride in the amount of 3, 6 and 10\% bwow (in relation to the amount of water). The following agents were successively added to the mixing water: defoaming, adjusting the setting and thickening time, plasticizing and reducing filtration. Cement slurries were made with the addition of $10 \%$ latex and a latex stabilizer in the amount of $1 \%$ bwoc (both components in relation to the weight of dry cement). The other ingredients: microcement (nanocement), microsilica, hematite and cement were mixed together and then added to the mixing water. All cement slurries were prepared on the basis of drilling cement G. When all components blended, the cement slurry was mixed for 30 minutes followed by laboratory measurements such as: density, fluidity, readings from the Fann apparatus, water retention, filtration, thickening time. From among the developed cement slurries, those with the best rheological parameters were selected, then samples of cement stones were prepared from them. Cement slurries were cured for 48 hours in an environment of high temperature and pressure (downhole conditions). The obtained cement stones were tested for: compressive strength, bending strength, porosity, adhesion of cement stone to steel pipes.

Key words: cement slurry, geothermal well, cement stone, rheological parameters, mechanical parameters, technological parameters.

\section{Wprowadzenie}

Firmy naftowe w ostatnich latach projektują i realizują w rejonie Karpat serię głębokich otworów, których końcowe głębokości przekraczają 3000 metrów. Temperatury dynamiczne panujące na dnie tych otworów dochodziły do $80-105^{\circ} \mathrm{C}$, a ciśnienia do 60-70 MPa. W przypadku takich głębokości otworów (w których występuje wysoka temperatura i ciśnienie) poważnym problemem jest zapewnienie długiego czasu przetłaczania zaczynu cementowego, który powinien charakteryzować się niską lepkością, niewielkim odstojem wody oraz jak najniższą filtracją. Należy zatem dobierać odpowiednie środki opóźniające i upłynniające, które są odporne na działanie wysokich temperatur, oraz inne dodatki zapewniające prawidłowe parametry technologiczne zaczynu i kamienia cementowego (Rzepka i Kątna, 2006; Kremieniewski i Rzepka, 2009; Rzepka, 2010; Kremieniewski, 2012, 2013; Rzepka i Kremieniewski, 2017).

Rejon Karpat stał się również interesujący dla hydrogeologów już na początku XX wieku jako obiekt potencjalnych zbiorników wód podziemnych. Wody geotermalne stanowią alternatywę dla tradycyjnych źródeł energetycznych, tj. ropy naftowej i gazu ziemnego. Rejon Karpat, zarówno wewnętrznych, jak i zewnętrznych, bogaty jest w zasoby energii geotermalnej niskotemperaturowej (temperatura poniżej $130^{\circ} \mathrm{C}$ ) zawartej w wodach wgłębnych, a związany jest głównie $\mathrm{z}$ basenami sedymentacyjnymi, zasobnymi też w złoża ropy naftowej i gazu ziemnego. Baseny sedymentacyjne zajmują ponad $50 \%$ powierzchni wszystkich kontynentów i są dobrze rozpoznane badaniami geofizycznymi i wierceniami wykonanymi przez przemysł naftowy, który prowadzi eksploatację złóż ropy naftowej od około
1853 roku, a gazu ziemnego od około 1900 roku. W basenach sedymentacyjnych, których na świecie istnieje około 194, złoża ropy i gazu zajmują 1-2\% ich powierzchni, a złoża wód geotermalnych - około 98\% (Sokołowski, 1999).

W rejonie południowo-wschodniej Polski w ostatnich latach okazało się, że najbardziej obiecujące pod względem zasobności w wody geotermalne są okolice Korczowej oraz Wiśniowej, gdzie odkryto obecność gorących wód na głębokościach przekraczających $3000 \mathrm{~m}$. Temperatury wód geotermalnych w tych rejonach oscylują w granicach $85-120^{\circ} \mathrm{C}$.

W INiG - PIB nie wykonywano do tej pory szczegółowych badań zaczynów cementowych o różnym stopniu zasolenia w temperaturze dynamicznej przekraczającej $90^{\circ} \mathrm{C}$ dla rejonu południowo-wschodniej Polski. Postęp prac wiertniczych w ostatnich latach sprawił, że zachodzi konieczność opracowania nowych receptur zaczynów cementowych do uszczelniania głębokich otworów, w szczególności geotermalnych. Ponadto wykonywanie otworów geotermalnych związane jest z występowaniem w przewiercanych formacjach wód termalnych o różnej mineralizacji. Obecność wód termalnych wymaga zastosowania do uszczelniania kolumny rur okładzinowych specjalnie opracowanych zaczynów cementowych zarabianych wodą o różnym stopniu zasolenia. Ze względu na duże zasoby oraz ogromny potencjał energetyczny, który znajduje się w wodach termalnych, zasadne jest prowadzenie prac związanych $\mathrm{z}$ udostępnianiem tych złóż. Specyficzne warunki otworowe oraz zróżnicowana mineralizacja wód w nich występujących podczas uszczelniania kolumny rur okładzinowych wymaga zastosowania specjalnie opracowanych innowacyjnych zaczynów uszczelniających, które utworzą szczelną i trwałą barierę z płaszcza cementowego. 
Oprócz czynników wpływających na skuteczność uszczelniania rur okładzinowych w otworach wiertniczych, takich jak prawidłowe przygotowanie otworu, technologia wykonania zabiegu, podstawową rolę odgrywa zaczyn cementowy, który powinien cechować się określonymi właściwościami. Skład i parametry zaczynu uzależnione są przede wszystkim od warunków geologicznych oraz hydrogeologicznych otworu, w którym następuje proces wiązania i tworzenia się kamienia cementowego, od rodzaju przewiercanych skał, głębokości, temperatury i ciśnienia na dnie otworu wiertniczego. Podczas realizacji tematu wykonano badania szeregu zaczynów cementowych proponowanych do uszczelniania kolumn rur okładzinowych w temperaturze dynamicznej do $130^{\circ} \mathrm{C}$ (Nalepa, 2001; Hodne, 2007; Dębińska, 2012; Machowski et al., 2013).

\section{Badania laboratoryjne}

Badaniom laboratoryjnym poddano szereg różnych składów zaczynów cementowych, zaś w artykule zamieszczono wyniki badań wytypowanych składów zaczynów (dla których uzyskano najlepsze parametry reologiczne), jak i otrzymanych z nich kamieni cementowych sporządzanych na bazie wody o różnym stopniu zasolenia. Wybrane receptury mogłyby posłużyć do uszczelniania kolumn rur okładzinowych

Tabela 1. Parametry technologiczne wybranych zaczynów cementowych dla warunków otworowych $90^{\circ} \mathrm{C}$ i $60 \mathrm{MPa}$

Table 1. Technological parameters of selected cement slurries for downhole conditions of $90^{\circ} \mathrm{C}$ and $60 \mathrm{MPa}$

\begin{tabular}{|c|c|c|c|c|c|c|c|}
\hline \multicolumn{2}{|l|}{ Ramowy skład zaczynu } & $\rho$ & Rozlewność & Filtracja & $\mathrm{Cz}_{\mathrm{g} 30}$ & $\mathrm{Cz}_{\mathrm{g} 100}$ & $\mathrm{Ws}_{28}$ \\
\hline \multicolumn{2}{|l|}{$[\%]$} & {$\left[\mathrm{kg} / \mathrm{m}^{3}\right]$} & [mm] & {$\left[\mathrm{cm}^{3} / 30 \mathrm{~min}\right]$} & \multicolumn{2}{|c|}{ [h:min] } & [MPa] \\
\hline $\begin{array}{l}\text { Woda } \\
\text { Odpieniacz } \\
\text { Upłynniacz } \\
\text { Dodatek antyfiltr. } \\
\text { Opóźniacz } \\
\text { KCl } \\
\text { Stabilizator lateksu } \\
\text { Lateks } \\
\text { Hematyt } \\
\text { Mikrosilika } \\
\text { Cement wiertniczy G } 100 \% \\
\text { Temperatura } \mathbf{9 0}^{\circ} \mathbf{C} / \text { ciśnienie } \mathbf{6 0} \mathbf{~ M P a ~ ( n r ~ 7 ) ~}\end{array}$ & $\begin{array}{c}\mathrm{w} / \mathrm{c}=0,45 \\
0,3 \% \text { bwoc } \\
0,5 \% \text { bwoc } \\
0,3 \% \text { bwoc } \\
0,05 \% \text { bwoc } \\
\mathbf{3 \%} \text { bwow } \\
1 \% \text { bwoc } \\
10 \% \text { bwoc } \\
10 \% \text { bwoc } \\
20 \% \text { bwoc }\end{array}$ & 1905 & 235 & 14 & $3: 57$ & $4: 54$ & 34,3 \\
\hline $\begin{array}{l}\text { Woda } \\
\text { Odpieniacz } \\
\text { Upłynniacz } \\
\text { Dodatek antyfiltr. } \\
\text { Opóźniacz } \\
\text { KCl } \\
\text { Stabilizator lateksu } \\
\text { Lateks } \\
\text { Hematyt } \\
\text { Mikrosilika } \\
\text { Cement wiertniczy G 100\% } \\
\text { Temperatura } \mathbf{9 0}^{\circ} \mathbf{C} / \text { ciśnienie }_{\mathbf{6 0}} \mathbf{M P a}(\mathbf{n r} \mathbf{1 0})\end{array}$ & $\begin{array}{c}\mathrm{w} / \mathrm{c}=0,45 \\
0,3 \% \text { bwoc } \\
0,7 \% \text { bwoc } \\
0,4 \% \text { bwoc } \\
0,07 \% \text { bwoc } \\
\mathbf{6 \%} \text { bwow } \\
1 \% \text { bwoc } \\
10 \% \text { bwoc } \\
10 \% \text { bwoc } \\
20 \% \text { bwoc }\end{array}$ & 1910 & 235 & 14 & $5: 48$ & $6: 51$ & 40,6 \\
\hline $\begin{array}{l}\text { Woda } \\
\text { Odpieniacz } \\
\text { Upłynniacz } \\
\text { Dodatek antyfiltr. } \\
\text { Opóźniacz } \\
\text { KCl } \\
\text { Stabilizator lateksu } \\
\text { Lateks } \\
\text { Hematyt } \\
\text { Mikrosilika } \\
\text { Cement wiertniczy G 100\% } \\
\text { Temperatura } \mathbf{9 0}^{\circ} \mathbf{C} / \text { ciśnienie }^{60} \mathbf{M P a}(\mathbf{n r} \mathbf{1 4})\end{array}$ & $\begin{array}{c}\mathrm{w} / \mathrm{c}=0,5 \\
0,3 \% \text { bwoc } \\
0,6 \% \text { bwoc } \\
0,4 \% \text { bwoc } \\
0,06 \% \text { bwoc } \\
\mathbf{1 0 \%} \text { bwow } \\
1 \% \text { bwoc } \\
10 \% \text { bwoc } \\
20 \% \text { bwoc } \\
10 \% \text { bwoc }\end{array}$ & 1910 & 260 & 20 & 4:03 & $6: 16$ & 29,6 \\
\hline
\end{tabular}

Oznaczenia:

$\rho$ - gęstość zaczynu cementowego

$\mathrm{Cz}_{\mathrm{g} 30}-$ czas gęstnienia $(30 \mathrm{Bc})$

$\mathrm{Cz}_{\mathrm{g} 100}$ - czas gęstnienia $(100 \mathrm{Bc})$

$\mathrm{Ws}_{28}$ - wytrzymałość kamienia cementowego na ściskanie po 28 dniach 
w głębokich otworach wiertniczych w rejonie Karpat. Badania prowadzono dla trzech różnych warunków ciśnienia i temperatury, tj.: $90^{\circ} \mathrm{C}$ i $60 \mathrm{MPa}, 110^{\circ} \mathrm{C}$ i $75 \mathrm{MPa}$ oraz $130^{\circ} \mathrm{C}$ i $80 \mathrm{MPa}$. Zaczyny cementowe zarabiano wodą wodociągową z dodatkiem chlorku potasu w ilości 3\%, 6\% i 10\% bwow (w stosunku do ilości wody). Do wody zarobowej dodawano kolejno środek regulujący czas wiązania, odpieniający, upłynniający i obniżający filtrację. Zaczyny cementowe sporządzono z dodatkiem lateksu w ilości 10\% i stabilizatora lateksu w ilości 1\% bwoc (oba składniki w stosunku do masy suchego cementu). Pozostałe składniki: mikrocement (nanocement), mikrosilikę, hematyt i cement mieszano ze sobą i wprowadzano następnie do wody zarobowej. Wszystkie zaczyny cementowe sporządzano na bazie cementu wiertniczego G (PN-EN ISO 10426-2).

Dla sporządzonych zaczynów cementowych wykonano następujące badania parametrów reologicznych: gęstość, rozlewność, odczyty z aparatu Fann, odstój wody, filtrację oraz czasy początku i końca gęstnienia. Opracowane próbki kamieni cementowych poddawano natomiast badaniom: wytrzymałości na ściskanie, zginanie, przyczepności do rur stalowych oraz porowatości.

Po sporządzeniu zaczynów cementowych zmierzono ich parametry reologiczne, a następnie z wybranych składów przygotowano próbki kamieni cementowych. Próbki wiązały w środowisku o określonej wyżej temperaturze i ciśnieniu (warunki otworopodobne). Następnie umieszczano je w autoklawach wykonanych ze stali nierdzewnej i przez cały okres sezonowania przetrzymywano w cieplarce. Otrzymane kamienie cementowe po założonych okresach poddawano badaniom laboratoryjnym.

W tabelach $1-5$ i na rysunkach $1-6$ przedstawiono szczegółowe wyniki badań parametrów technologicznych zaczynów i kamieni cementowych z wybranych receptur. W artykule zamieszczono wyniki badań dla dwóch wariantów warunków otworopodobnych: $90^{\circ} \mathrm{C}$ i $60 \mathrm{MPa}$ oraz $110^{\circ} \mathrm{C}$ i $75 \mathrm{MPa}$. Przeprowadzone badania dla $130^{\circ} \mathrm{C}$ i $80 \mathrm{MPa}$ wykazały, że opracowane receptury posiadały dobre parametry reologiczne, jednak otrzymane próbki kamieni cementowych po 28 dniach sezonowania miały niskie parametry mechaniczne i ich poprawa wymaga dalszych badań laboratoryjnych (Kut, 2011).

Niepewność uzyskanych wyników pomiarów zaprezentowanych poniżej oznaczono na podstawie klasy dokładności urządzeń pomiarowych na poziomie: dla pomiarów reologicznych $-0,2 \%$, dla pomiarów wytrzymałości na ściskanie oraz przyczepność do rur - 0,4\%.

Pierwsze badania wykonywano dla temperatury dynamicznej wynoszącej $90^{\circ} \mathrm{C}$ oraz ciśnienia $60 \mathrm{MPa}$, zadając symulowany czas dojścia do temperatury wynoszący 60 minut. Podczas sporządzania zaczynów cementowych wykorzystywano takie same składniki, jakie stosuje serwis cementacyjny podczas cementowania otworów wiertniczych w rejonie południowo-wschodniej Polski (tab. 1).
Tabela 2. Parametry mechaniczne kamieni cementowych dla warunków otworowych $90^{\circ} \mathrm{C}$ i $60 \mathrm{MPa}$

Table 2. Mechanical parameters of cement stones for downhole conditions of $90^{\circ} \mathrm{C}$ and $60 \mathrm{MPa}$

\begin{tabular}{|c|c|c|c|c|}
\hline \multirow{2}{*}{ Nr } & \multicolumn{5}{|c|}{ Temperatura 90 ${ }^{\circ} \mathbf{C}$} \\
\cline { 2 - 5 } & \multicolumn{4}{|c|}{ Wytrzymalość na ściskanie [MPa] } \\
\cline { 2 - 5 } & po 2 dniach & po 7 dniach & po 14 dniach & po 28 dniach \\
\hline \hline 7 & 28,9 & 31,8 & 33,9 & 34,3 \\
\hline 10 & 31,3 & 37,4 & 37,8 & 40,6 \\
\hline 14 & 20,0 & 24,6 & 29,4 & 29,6 \\
\hline \multirow{5}{*yyyy}{} & \multicolumn{5}{|c|}{ Wytrzymalość na zginanie [MPa] } \\
\hline 7 & 12,0 & 12,0 & 10,5 & 10,5 \\
\hline 10 & 10,5 & 11,3 & 12,0 & 12,0 \\
\hline 14 & 10,5 & 11,3 & 10,5 & 10,5 \\
\hline & \multicolumn{5}{|c|}{ Przyczepność do rur stalowych [MPa] } \\
\hline 7 & 4,6 & 5,1 & 4,9 & 7,5 \\
\hline 10 & 3,8 & 4,0 & 4,6 & 4,9 \\
\hline 14 & 3,2 & 2,8 & 2,9 & 3,0 \\
\hline
\end{tabular}

Receptury sporządzano przy dodatku 3\%, 6\% i 10\% KCl. Zaczyny te miały gęstości od $1905 \mathrm{~kg} / \mathrm{m}^{3}$ do $1910 \mathrm{~kg} / \mathrm{m}^{3}$ oraz wyróżniały się brakiem odstoju wody. Wybrane receptury posiadały niskie filtracje, nieprzekraczające $20 \mathrm{~cm}^{3} / 30 \mathrm{~min}$. Rozlewności wynosiły od $235 \mathrm{~mm}$ do $260 \mathrm{~mm}$. Dla wytypowanych próbek otrzymano odpowiednie czasy gęstnienia w danych warunkach otworowych, osiągając początki gęstnienia (30 Bc) powyżej 3 h 50 min i więcej, zaś koniec gęstnienia (konsystencję $100 \mathrm{Bc}$ ) dla tych składów - poniżej $7 \mathrm{~h}$. W tabeli 2 i na rysunkach 1-3 zamieszczono wyniki badań parametrów mechanicznych kamieni cementowych sezonowanych w $90^{\circ} \mathrm{C}$.

Wykonane badania wytrzymałości na ściskanie w temperaturze $90^{\circ} \mathrm{C}$ wykazały jej wzrost po każdym okresie badań - po 28 dniach wynosiła ona od 29,6 MPa do 40,6 MPa, przy czym najmocniejsza była próbka nr 10, z zawartością $6 \% \mathrm{KCl}$, $10 \%$ hematytu i $20 \%$ mikrosiliki.

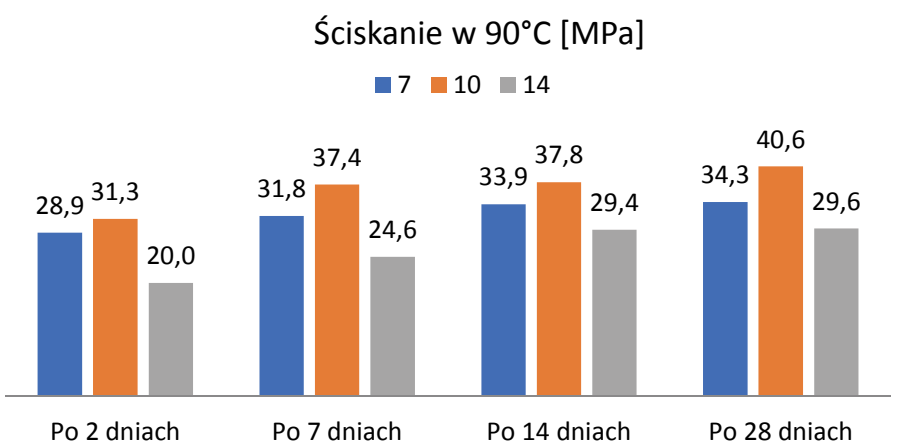

Rys. 1. Wytrzymałość kamieni cementowych na ściskanie w temperaturze $90^{\circ} \mathrm{C}$

Fig. 1. Compressive strength of cement stones at $90^{\circ} \mathrm{C}$ 
Przyczepność w $90^{\circ} \mathrm{C}[\mathrm{MPa}]$

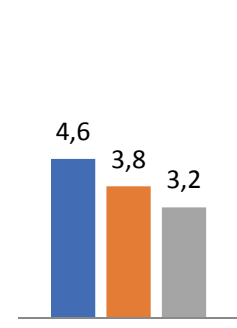

Po 2 dniach

$$
\because 7 \quad 10 \quad 14
$$

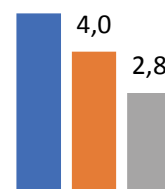

Po 7 dniach
7,5

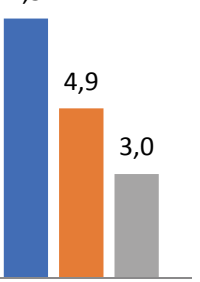

Po 28 dniach

Rys. 2. Przyczepność kamieni cementowych do rur stalowych w temperaturze $90^{\circ} \mathrm{C}$

Fig. 2. Adhesion of cement stones to steel pipes at $90^{\circ} \mathrm{C}$

Zginanie w $90^{\circ} \mathrm{C}[\mathrm{MPa}]$

$\because 7 \quad 10 \square 14$

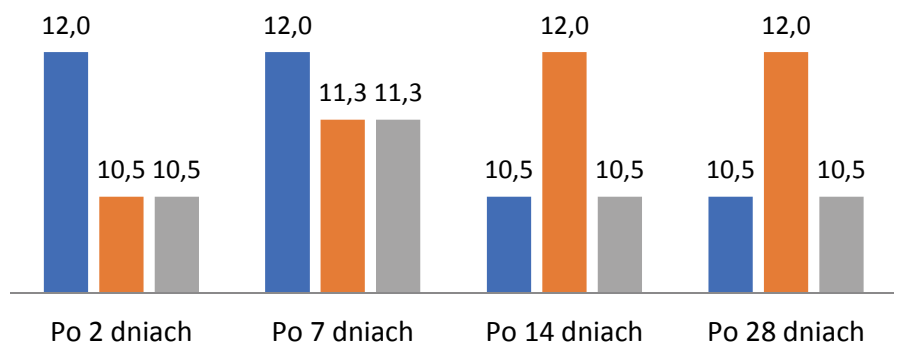

Rys. 3. Wytrzymałość kamieni cementowych na zginanie w temperaturze $90^{\circ} \mathrm{C}$

Fig. 3. Bending strength of cement stones at $90^{\circ} \mathrm{C}$

Tabela 3. Parametry technologiczne wybranych zaczynów cementowych w warunkach otworowych $110^{\circ} \mathrm{C}$ i $75 \mathrm{MPa}$

Table 3. Technological parameters of selected cement slurries for downhole conditions of $110^{\circ} \mathrm{C}$ and $75 \mathrm{MPa}$

\begin{tabular}{|c|c|c|c|c|c|c|c|}
\hline \multicolumn{2}{|l|}{ Ramowy sklad zaczynu } & $\rho$ & Rozlewność & Filtracja & $\mathrm{Cz}_{\mathrm{g} 30}$ & $\mathrm{Cz}_{\mathrm{g} 100}$ & $\mathrm{Ws}_{28}$ \\
\hline \multicolumn{2}{|l|}{$[\%]$} & {$\left[\mathrm{kg} / \mathrm{m}^{3}\right]$} & {$[\mathrm{mm}]$} & {$\left[\mathrm{cm}^{3} / 30 \mathrm{~min}\right]$} & \multicolumn{2}{|c|}{ [h:min] } & [MPa] \\
\hline $\begin{array}{l}\text { Woda } \\
\text { Odpieniacz } \\
\text { Upłynniacz } \\
\text { Dodatek antyfiltr. } \\
\text { Opóźniacz } \\
\text { KCl } \\
\text { Stabilizator lateksu } \\
\text { Lateks } \\
\text { Hematyt } \\
\text { Mikrosilika } \\
\text { Cement wiertniczy G } 100 \% \\
\text { Temperatura } \mathbf{1 1 0}^{\circ} \mathbf{C} / \text { ciśnienie }^{\mathbf{7 5}} \mathbf{~ M P a ~ ( n r ~ 1 8 ) ~}\end{array}$ & $\begin{array}{c}\mathrm{w} / \mathrm{c}=0,5 \\
0,3 \% \text { bwoc } \\
1,0 \% \text { bwoc } \\
0,4 \% \text { bwoc } \\
0,27 \% \text { bwoc } \\
\mathbf{3 \%} \text { bwow } \\
1 \% \text { bwoc } \\
10 \% \text { bwoc } \\
50 \% \text { bwoc } \\
20 \% \text { bwoc }\end{array}$ & 2080 & 245 & 12 & $6: 44$ & $7: 25$ & 24,3 \\
\hline $\begin{array}{l}\text { Woda } \\
\text { Odpieniacz } \\
\text { Upłynniacz } \\
\text { Dodatek antyfiltr. } \\
\text { Opóźniacz } \\
\text { KCl } \\
\text { Stabilizator lateksu } \\
\text { Lateks } \\
\text { Hematyt } \\
\text { Mikrosilika } \\
\text { Cement wiertniczy G } 100 \% \\
\text { Temperatura } \mathbf{1 1 0}^{\circ} \mathbf{C} / \text { ciśnienie }^{\mathbf{7 5}} \mathbf{~ M P a ~ ( n r ~ 2 3 ) ~}\end{array}$ & $\begin{array}{c}\mathrm{w} / \mathrm{c}=0,55 \\
0,3 \% \text { bwoc } \\
1,0 \% \text { bwoc } \\
0,5 \% \text { bwoc } \\
0,24 \% \text { bwoc } \\
\mathbf{6 \%} \text { bwow } \\
1 \% \text { bwoc } \\
10 \% \text { bwoc } \\
60 \% \text { bwoc } \\
10 \% \text { bwoc }\end{array}$ & 2090 & 230 & 26 & $3: 31$ & $5: 15$ & 21,4 \\
\hline $\begin{array}{l}\text { Woda } \\
\text { Odpieniacz } \\
\text { Upłynniacz } \\
\text { Dodatek antyfiltr. } \\
\text { Opóźniacz } \\
\text { KCl } \\
\text { Stabilizator lateksu } \\
\text { Lateks } \\
\text { Hematyt } \\
\text { Mikrosilika } \\
\text { Cement wiertniczy G } 100 \% \\
\text { Temperatura } \mathbf{1 1 0}^{\circ} \mathbf{C} / \text { ciśnienie }^{75} \mathbf{~ M P a ~ ( n r ~ 2 6 ) ~}\end{array}$ & $\begin{array}{c}\mathrm{w} / \mathrm{c}=0,55 \\
0,3 \% \text { bwoc } \\
1,0 \% \text { bwoc } \\
0,4 \% \text { bwoc } \\
0,24 \% \text { bwoc } \\
\mathbf{1 0 \%} \text { bwow } \\
1 \% \text { bwoc } \\
10 \% \text { bwoc } \\
50 \% \text { bwoc } \\
10 \% \text { bwoc }\end{array}$ & 2030 & 235 & 30 & $6: 11$ & $6: 28$ & 26,5 \\
\hline
\end{tabular}

Oznaczenia:

$\rho$ - gęstość zaczynu cementowego

$\mathrm{Cz}_{\mathrm{g} 30}$ - czas gęstnienia $(30 \mathrm{Bc})$

$\mathrm{Cz}_{\mathrm{g} 100}$ - czas gęstnienia $(100 \mathrm{Bc})$

$\mathrm{Ws}_{28}$ - wytrzymałość kamienia cementowego na ściskanie po 28 dniach 
Drugim mierzonym parametrem mechanicznym kamieni cementowych była ich przyczepność do rur stalowych. Wykonane badania wykazały, że po 28 dniach wartości przyczepności do rur stalowych dla temperatury $90^{\circ} \mathrm{C}$ wynosiły od 3,0 MPa do 7,5 MPa, a najmocniejsza była próbka $\mathrm{nr}$ 7, z zawartością 3\% KCl, 10\% hematytu i $20 \%$ mikrosiliki.

Trzecim i ostatnim badaniem, którego wyniki zamieszczono w tabeli 2, były pomiary odporności kamieni cementowych na zginanie. Dla wszystkich przebadanych próbek po 28 dniach ich sezonowania otrzymano zbliżone wartości wynoszące od 9,0 MPa do 12,0 MPa.

Kolejne badania wykonano dla temperatury dynamicznej wynoszącej $110^{\circ} \mathrm{C}$ oraz ciśnienia $75 \mathrm{MPa}$, zadając symulowany czas dojścia do temperatury wynoszący 90 minut (tabela 3 ).

Również dla tych warunków otworowych receptury sporządzano z dodatkiem 3\%, 6\% i $10 \% \mathrm{KCl}$. Zaczyny te miały gęstości od $2030 \mathrm{~kg} / \mathrm{m}^{3}$ do $2090 \mathrm{~kg} / \mathrm{m}^{3}$. Odstój wody wynosił zero. Wszystkie receptury posiadały niskie filtracje, wynoszące od $12 \mathrm{~cm}^{3} / 30 \mathrm{~min}$ do $30 \mathrm{~cm}^{3} / 30 \mathrm{~min}$. Rozlewności wynosiły od $230 \mathrm{~mm}$ do $245 \mathrm{~mm}$, co świadczy o dobrej płynności zaczynów cementowych. Opracowane receptury posiadały odpowiednie czasy gęstnienia, konsystencję 30 Bc uzyskiwały powyżej $3 \mathrm{~h} 30 \mathrm{~min}$, a $100 \mathrm{Bc}$ (koniec gęstnienia - brak przetłaczalności) poniżej 7 h 30 min. W tabeli 4 i na rysunkach 4-6 zamieszczono wyniki badań parametrów mechanicznych kamieni cementowych sezonowanych w $110^{\circ} \mathrm{C}$.

Próbki kamieni cementowych sezonowanych $\mathrm{w} 110^{\circ} \mathrm{C}$ cechowały się nieznacznie niższymi wartościami wytrzymałości na ściskanie niż te opracowane dla temperatur $90^{\circ} \mathrm{C}$ i po 28 dniach wynosiły od 21,4 MPa do 26,5 MPa. Po 28 dniach

Tabela 4. Parametry mechaniczne kamieni cementowych w warunkach otworowych $110^{\circ} \mathrm{C}$ i $75 \mathrm{MPa}$

Table 4. Mechanical parameters of cement stones for downhole conditions of $110^{\circ} \mathrm{C}$ and $75 \mathrm{MPa}$

\begin{tabular}{|c|c|c|c|c|}
\hline \multirow{2}{*}{ Nr } & \multicolumn{4}{|c|}{ Temperatura 110 ${ }^{\circ} \mathbf{C}$} \\
\cline { 2 - 5 } & \multicolumn{4}{|c|}{ Wytrzymałość na ściskanie [MPa] } \\
\cline { 2 - 5 } & po 2 dniach & po 7 dniach & po 14 dniach & po 28 dniach \\
\hline \hline 18 & 24,6 & 24,9 & 24,0 & 24,3 \\
\hline 23 & 17,7 & 20,3 & 22,9 & 21,4 \\
\hline 26 & 26,7 & 25,0 & 27,3 & 26,5 \\
\hline \multirow{5}{*yyyy}{} & \multicolumn{5}{|c|}{ Wytrzymalość na zginanie [MPa] } \\
\hline 18 & 10,5 & 11,3 & 12,0 & 12,0 \\
\hline 23 & 9,0 & 9,8 & 11,3 & 11,3 \\
\hline 26 & 9,0 & 9,0 & 9,8 & 9,8 \\
\hline & 4,3 & 4,6 & 4,9 & 6,6 \\
\hline 18 & 3,7 & 3,8 & 3,6 & 4,3 \\
\hline 23 & 2,6 & 2,8 & 3,2 & 3,3 \\
\hline 26 & \multicolumn{5}{|c|}{ Przyczepność do rur stalowych [MPa] } \\
\hline
\end{tabular}

Ściskanie w $110^{\circ} \mathrm{C}[\mathrm{MPa}]$

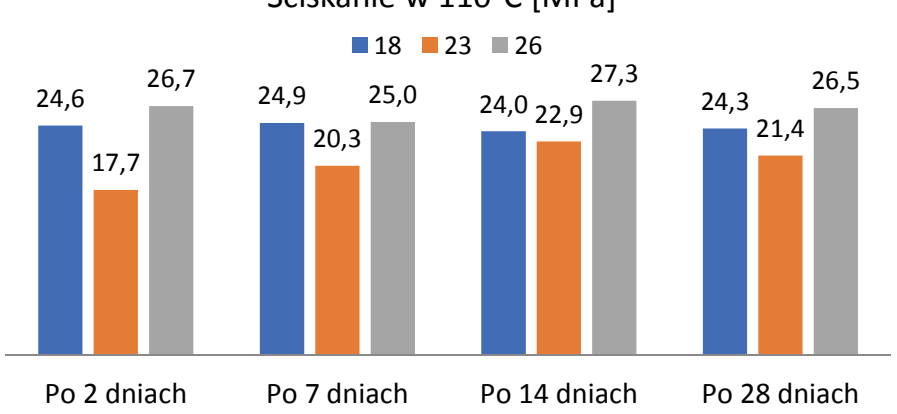

Rys. 4. Wytrzymałość kamieni cementowych na ściskanie w temperaturze $110^{\circ} \mathrm{C}$

Fig. 4. Compressive strength of cement stones at $110^{\circ} \mathrm{C}$

\section{Przyczepność w $110^{\circ} \mathrm{C}[\mathrm{MPa}]$}

$\square 18 \square 23 \quad 26$

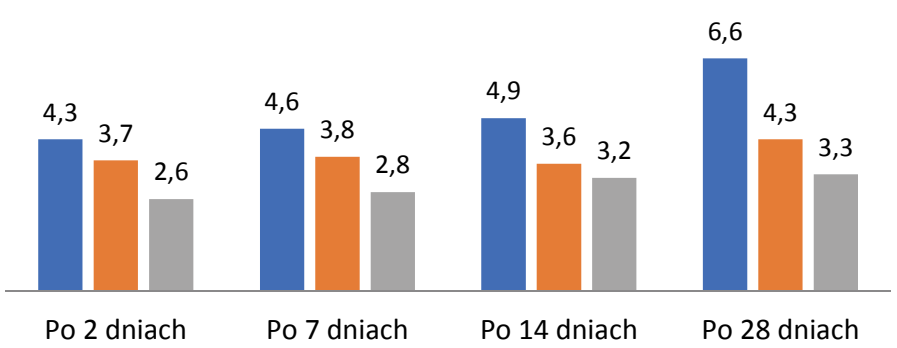

Rys. 5. Przyczepność kamieni cementowych do rur stalowych w temperaturze $110^{\circ} \mathrm{C}$

Fig. 5. Adhesion of cement stones to steel pipes at $110^{\circ} \mathrm{C}$
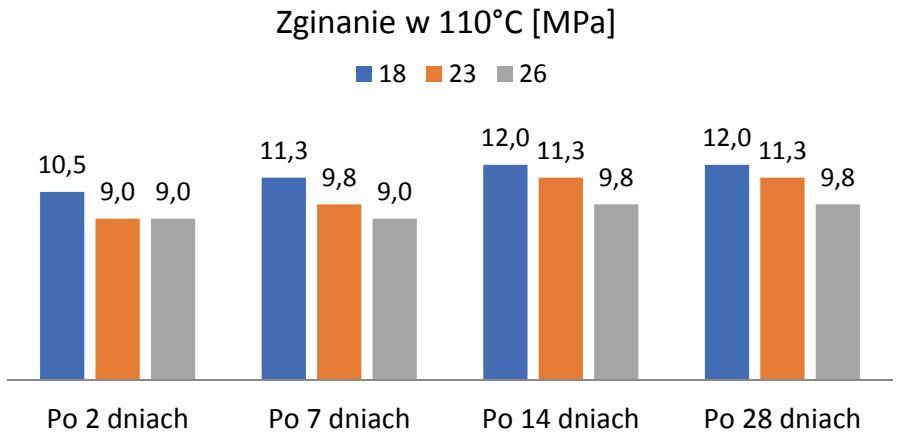

Rys. 6. Wytrzymałość kamieni cementowych na zginanie w temperaturze $110^{\circ} \mathrm{C}$

Fig. 6. Bending strength of cement stones at $110^{\circ} \mathrm{C}$

spośród próbek sezonowanych $\mathrm{w} 110^{\circ} \mathrm{C}$ najmocniejsza okazała się ta z zawartością $10 \% \mathrm{KCl}, 50 \%$ hematytu i $10 \%$ mikrosiliki, a jej wytrzymałość wyniosła 26,5 MPa (próbka nr 26).

Drugim mierzonym parametrem mechanicznym kamieni cementowych była ich przyczepność do rur stalowych. Wykonane badania wykazały, że po 28 dniach wartości przyczepności do rur stalowych dla temperatury $110^{\circ} \mathrm{C}$ były porównywalne do tych zmierzonych dla temperatury $90^{\circ} \mathrm{C}$, a najmocniejsza okazała się próbka $\mathrm{nr} 18$, z zawartością $3 \% \mathrm{KCl}$, $50 \%$ hematytu i $20 \%$ mikrosiliki, dla której uzyskano wartość 6,6 MPa. 


\section{NAFTA-GAZ}

Ostatnim badaniem, którego wyniki zamieszczono w tabeli 4, były pomiary odporności kamieni cementowych na zginanie. Dla wszystkich przebadanych próbek po 28 dniach sezonowania otrzymano zbliżone wartości, wynoszące od 9,0 $\mathrm{MPa}$ do $12,0 \mathrm{MPa}$

Ostatnim etapem było wykonanie badań porowatości wybranych próbek kamieni cementowych przy użyciu porozymetru rtęciowego po 28 dniach ich sezonowania. Porowatości wszystkich próbek mieściły się w przedziale od 33,7\% do $40,3 \%$. Najniższą porowatość po 28 dniach posiadała próbka otrzymana ze składu nr 10, która zawierała 10\% hematytu, $20 \%$ mikrosiliki oraz $6 \% \mathrm{KCl}$. Wskaźnik w/c wynosił 0,45 . Najwyższą z kolei porowatość odnotowano w przypadku próbki nr 14, zawierającej 20\% hematytu, 10\% mikrosiliki oraz $10 \% \mathrm{KCl}$, o wskaźniku wodno-cementowym w/c wynoszącym 0,5 . W tabelach 5 i 6 przedstawiono wyniki badań dla wybranych próbek kamieni cementowych. Zgodnie z otrzymanymi wynikami największą ilość stanowią pory z przedziału wielkości 10 000-100 nm - od 70\% do 95\%.

Tabela 5. Porowatości wybranych próbek kamieni cementowych po 28 dniach ich sezonowania

Table 5. Porosity of selected samples of cement stones after 28 days of sample seasoning

\begin{tabular}{|c|c|}
\hline Nr próbki & Porowatość [\%] \\
\hline \hline 7 & 35,7 \\
\hline 10 & 33,7 \\
\hline 14 & 40,3 \\
\hline 18 & 34,3 \\
\hline 23 & 38,9 \\
\hline 26 & 39,2 \\
\hline
\end{tabular}

Tabela 6. Wykresy rozkładów porów w wybranych próbkach

Table 6. Charts of pore distribution in selected samples

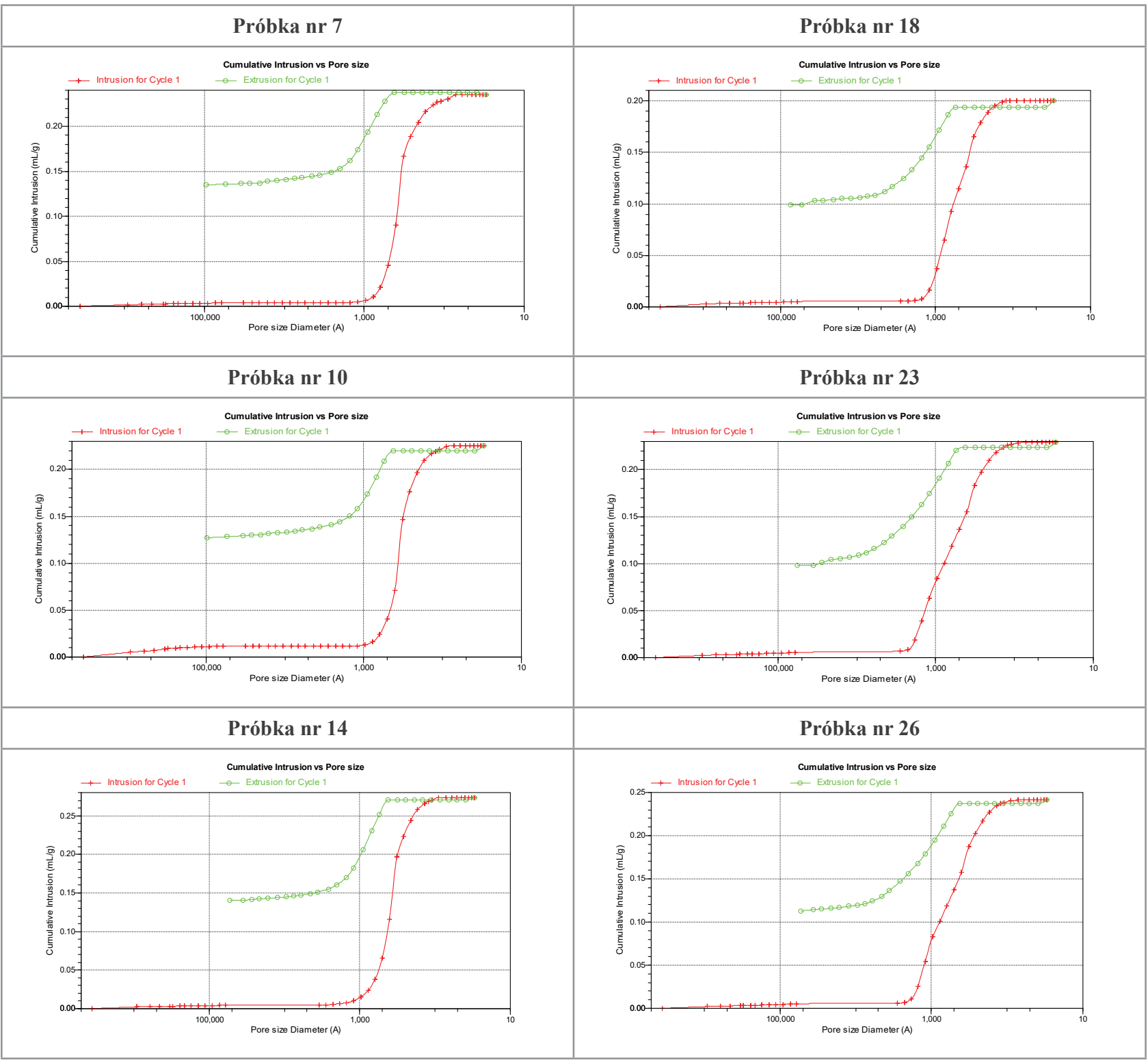




\section{Podsumowanie i wnioski}

1. Na podstawie przeprowadzonych badań wytypowanych składów zaczynów cementowych można wyciągnąć następujące wnioski:W wyniku badań laboratoryjnych opracowano receptury zaczynów uszczelniających dla temperatury dynamicznej około $90-110^{\circ} \mathrm{C}$ i ciśnienia około 60-75 MPa. Zaczyny te zarabiane były wodą zasoloną chlorkiem potasu w ilościach 3\%,6\% i 10\%.

2. Opisane w artykule zaczyny cementowe posiadały gęstości od $1905 \mathrm{~kg} / \mathrm{m}^{3}$ do $2090 \mathrm{~kg} / \mathrm{m}^{3}$ i zostały opracowane z myślą o zastosowaniu ich podczas uszczelniania kolumn rur okładzinowych głównie w rejonie Karpat.

3. Parametry technologiczne opracowanych zaczynów cementowych można było z powodzeniem regulować dodatkami powszechnie stosowanymi w krajowym przemyśle wiertniczym.

4. Zaczyny cementowe po użyciu odpowiednich proporcji środków chemicznych (do danych warunków otworopodobnych) charakteryzowały się dobrymi parametrami reologicznymi.

5. Żaden z przedstawionych zaczynów cementowych nie wykazał odstoju wody, zaś zmierzone filtracje wynosiły od $12,0 \mathrm{~cm}^{3} / 30 \mathrm{~min}$ (nr 18) do $30,0 \mathrm{~cm}^{3} / 30 \mathrm{~min}$ (nr 26).

6. Badania wykazały, że rozlewność mieściła się w przedziale od $230 \mathrm{~mm}$ (nr 23) do $260 \mathrm{~mm}$ (nr 14).

7. Czasy gęstnienia opracowanych zaczynów cementowych mieściły się w przedziale od około 4 godzin do około 7,5 godziny i można je z powodzeniem regulować za pomocą dodatku środka opóźniającego w ilości około 0,05-0,65\%.

8. Kamienie cementowe powstałe po związaniu opracowanych zaczynów cechowały się wysokimi parametrami mechanicznymi głównie dla temperatur $90^{\circ} \mathrm{C}$ i $110^{\circ} \mathrm{C}$. Już po 2 dniach wytrzymałość na ściskanie większości badanych próbek kamieni cementowych przekraczała $20 \mathrm{MPa}$, natomiast po 28 dniach hydratacji wytrzymałość na ściskanie osiągała nawet wartości około $40 \mathrm{MPa}$ (próbka nr 10 $-90^{\circ} \mathrm{C}, 65 \mathrm{MPa}$ i $6 \% \mathrm{KCl}$ ). Przyczepność kamienia cementowego do rur stalowych była również bardzo wysoka (po 2 dniach wynosiła około 2,6-4,6 MPa, a po 28 dniach wzrastała do około 3-7,5 $\mathrm{MPa}$ ).

9. Przeprowadzone badania wytrzymałości kamieni cementowych na zginanie dla dwóch temperatur, $90^{\circ} \mathrm{C} \mathrm{i} 110^{\circ} \mathrm{C}$, wykazały, że zarówno po 2 dniach, jak i po 28 dniach sezonowania próbek zmierzone wartości mieściły się w przedziale od $9 \mathrm{MPa}$ do $12 \mathrm{MPa}$.

10. Opracowane receptury zaczynów mogą znaleźć zastosowanie w procesie cementowania kolumn rur okładzinowych w warunkach wysokich temperatur i ciśnień złożowych w środowisku o różnym stopniu zasolenia, które to warunki mogą występować podczas wierceń otworów sięgających głębokości 3500-5000 metrów.

Artykuł powstał na podstawie pracy statutowej pt. Opracowanie zaczynów cementowych do uszczelniania otworów o podwyzszonych temperaturach $w$ rejonie Karpat - praca INiG - PIB na zlecenia MNiSW; nr zlecenia: 0026/KW/2020, nr archiwalny: DK-4100-0014/2020.

\section{Literatura}

Dębińska E., 2012. Ocena działania dodatków opóźniających czas wiązania zaczynów cementowych na podstawie badań laboratoryjnych. Nafta-Gaz, 4: 225-232.

Hodne H., 2007. Rheological performance of cementitious materials used in well cementing. Faculty of Science and Technology Department of Petroleum Engineering, Stavanger.

Kremieniewski M., 2012. Modyfikacja przestrzeni porowej kamieni cementowych. Nafta-Gaz, 3: 165-170.

Kremieniewski M., 2013. Wpływ warunków hydratacji na strukturę przestrzenną kamieni cementowych. Nafta-Gaz, 1: 51-56.

Kremieniewski M., Rzepka M., 2009. Wpływ procesu ogrzewania na reologię modyfikowanych zaczynów cementowych. NaftaGaz, 10: 775-781.

Kut Ł., 2011. Wpływ mikrocementu na parametry zaczynu i kamienia cementowego. Nafta-Gaz, 12: 903-908.

Machowski W., Machowski G., Białecka K., 2013. Ocena możliwości pracy dubletu geotermalnego na strukturze Wiśniowej koło Strzyżowa jako wynik modelowań dynamicznych. Technika Poszukiwań Geologicznych, 2: 95-104.

Nalepa J., 2001. Problemy związane z cementowaniem głębokich otworów wiertniczych. Sympozjum Naukowo-Techniczne, Cementy w budownictwie, robotach wiertniczych i inżynieryjnych oraz hydrotechnice, Piła-Plotki.

Rzepka M., 2010. Zaczyny cementowe do uszczelniania kolumn rur okładzinowych w głębokich otworach wiertniczych w temperaturze dynamicznej do ok. $120^{\circ} \mathrm{C}$. Nafta-Gaz, 4: 274-279.

Rzepka M., Kątna Z., 2006. Zaczyny cementowe z dodatkiem mikrocementu do uszczelniania rur okładzinowych w warunkach wysokich temperatur i ciśnień złożowych. Nafta-Gaz, 7-8: 364-369.

Rzepka M., Kremieniewski M., 2017. Zaczyny cementowe do uszczelniania głębokich otworów wiertniczych. Oil and Gas Engineering, Poltava National Technical University, 2: 43-56.

Sokołowski J., 1999. Możliwości zagospodarowania wód geotermalnych w trzech prowincjach Europy północno-zachodniej i centralnej stykających się w rejonie Krakowa. Technika Poszukiwań Geologicznych, 4-5: 77-97.

\section{Akty prawne i dokumenty normatywne}

PN-EN ISO 10426-2 Przemysł naftowy i gazowniczy. Cementy i materiały do cementowania otworów wiertniczych. Część 2: Badania cementów wiertniczych.

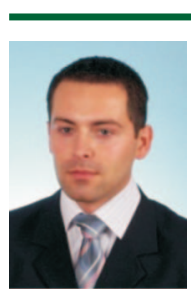

Mgr inż. Łukasz KUT

Starszy specjalista badawczo-techniczny w Zakładzie Technologii Wiercenia

Instytut Nafty i Gazu - Państwowy Instytut Badawczy ul. Lubicz 25 A

31-503 Kraków

E-mail: lukasz.kut@inig.pl 